\title{
O método intuitivo na Arithmetica Primaria de Trajano
}

\author{
The intuitive method in Arithmetica Primaria of Trajano
}

\author{
Rogerio dos Santos Carneiro ${ }^{1}$ \\ Lucia Maria Aversa Villela ${ }^{2}$
}

\begin{abstract}
Resumo
O presente artigo pauta-se em uma pesquisa em torno da conceituação e da disseminação do método intuitivo no Brasil e a sua presença na obra Arithmetica Primaria, de Antônio Bandeira Trajano. Tem um aporte teóricometodológico da História Cultural, fundamentado por Roger Chartier, André Chervel, Alain Choppin e Dominique Julia, dentre outros autores/pesquisadores. Os dados levantados foram colhidos em livros, recortes de jornais, leis, decretos, dentre outros registros. A análise das fontes revelou "novas" práticas pedagógicas, mudanças de significado para o ensino de número e a introdução de novos conteúdos na Aritmética escolar, à medida que vinha sendo constatada a presença do ensino alicerçado pelo método intuitivo na aritmética primária de Trajano. Observou-se a importância deste livro, e de seu autor, para os desenvolvimentos educacionais vivenciados durante o século XIX e início do século XX.
\end{abstract}

Palavras-chave: Aritmetica; Método Intuitivo; História da Educação Matemática.

\begin{abstract}
The present article is based on a research about the conceptualization and dissemination of the intuitive method in Brazil and its presence in the Arithmetica Primaria, by Antonio Bandeira Trajano. There is a theoreticalmethodological contribution of Cultural History, founded by Roger Chartier, André Chervel, Alain Choppin and Dominique Julia, among other authors / researchers. The data collected in this research were collected from books, newspaper clippings, laws, decrees, and other records based on this research. The analysis of the sources revealed "new" pedagogical practices, changes of meaning for the teaching of number and the introduction of new contents in school Arithmetic, as the presence of the teaching based on the intuitive method in the primary arithmetic of Trajano was verified. It was observed the importance of the book, and its author, for the educational developments experienced during the nineteenth and early twentieth centuries
\end{abstract}

Keywords: Arithmetic; Intuitive Method; History of Mathematics Education.

\section{Introdução}

Para produzir história da educação matemática é importante a aproximação com o campo da história, tendo como finalidade atribuir sentido ao fazer historiográfico na

\footnotetext{
Submetido em: 27/11/2018 - Aceito em: 15/04/2019 - Publicado em: 15/04/2019

${ }^{1}$ Doutorando em Educação em Ciências e Matemática, pela Rede Amazônica de Educação em Ciências e Matemática (REAMEC), Universidade Federal de Mato Grosso (UFMT). Professor da Licenciatura em Matemática, Universidade Federal do Tocantins (UFT), Câmpus de Araguaína. E-mail: rogerioscarneiro@gmail.com ${ }^{2}$ Doutora em Educação Matemática, pela Universidade Bandeirante de São Paulo (UNIBAN). Pesquisadora do
GHEMAT - Brasil. E-mail: luciavillela@globo.com
} 
DOI: https://doi.org/ 10.20396/zet.v27i0.8654072

perspectiva histórico-cultural. A concepção do estudo da história da educação matemática escolhida evidencia

a necessidade de trazer de volta, à mesa de discussão, o passado da educação matemática, em termos de sua representação, não tem caráter saudosista. Os rastros desse passado, presentes na contemporaneidade da educação matemática, indicam a necessidade de compreender historicamente como as descontinuidades de outros tempos históricos deixaram marcas nas práticas pedagógicas presentes nas salas de aula da atualidade. Mais que isso: é imperativo ampliar o debate presente sobre a educação matemática trazendo a história da educação matemática como um participante ativo da discussão. (Valente, 2011, p. 2)

Com base na visão de Antoine Prost, Valente (2007) afirma que "os fatos históricos são constituídos a partir de traços, de rastros deixados no presente pelo passado" (p. 31). A aproximação com o campo da história permite levantar questionamentos para que possamos recolher registros do passado e, a partir daí, procurar compreender a trajetória seguida por diversos segmentos, em especial o nosso objeto de estudo, que é o uso do método intuitivo na Arithmética Primaria, de Trajano.

Certeau (2007) aborda a história com um "novo olhar" e também com um "novo dizer", o que contribuiu para a renovação da prática historiográfica. Ressalta ele que o gosto do historiador liga suas ideias aos lugares de onde fala. A construção dos fatos históricos parte de uma análise da realidade e se articula com a produção socioeconômica, política e cultural.

A articulação da história com um lugar é a condição de uma análise da sociedade. ... Levar a sério o seu lugar não é ainda explicar a história. Mas é a condição para que alguma coisa possa ser dita sem ser nem legendária (ou "edificante"), nem a-tópica (sem pertinência). Sendo a denegação da particularidade do lugar o próprio princípio do discurso ideológico, ela exclui toda a teoria. (p. 77)

Esclarece, ainda, Certeau (2007), que o historiador elabora seu trabalho a partir do presente, das preocupações de sua realidade, fazendo de sua fala um "discurso particularizado", que tem um emissor, o historiador, e um destinatário, seja ele qual for: a academia, a sociedade de forma geral ou um grupo específico. Essa discussão implicou numa constatação: "não se pode falar de uma verdade, mas de verdades (no plural)" (p. 67).

A análise criteriosa da história cultural, afirma Roger Chartier (1990), é importante para identificar o modo como, em diferentes lugares e momentos, uma realidade social é construída, pensada, dada a ler. Portanto, ao voltar-se para a vida social, esse campo pode tomar por objeto as formas e os motivos das suas representações e pensá-las como análise do trabalho de representação das classificações e das exclusões que constituem as configurações sociais e conceituais de um tempo ou de um espaço. No entanto, a história cultural deve ser entendida como o estudo dos processos com os quais se constrói um sentido, uma vez que as representações podem ser pensadas como "esquemas intelectuais, que criam as figuras graças às quais o presente pode adquirir sentido, o outro tornar-se inteligível e o espaço ser decifrado" (p. 17).

Zetetiké, Campinas, SP, v.27, 2019, p.1-20 - e019010

ISSN 2176-1744 
DOI: https://doi.org/ 10.20396/zet.v27i0.8654072

Quanto à história das produções escolares, Julia (2001) diz que:

Ela tenta identificar, tanto através das práticas de ensino utilizadas na sala de aula como através dos grandes objetivos que presidiram a constituição das disciplinas, o núcleo duro que pode constituir uma história renovada da educação. Ela abre, em todo caso, para retomar uma metáfora aeronáutica, a "caixa preta" da escola, ao buscar compreender o que ocorre nesse espaço particular. (p. 13)

As pesquisas no campo da história das disciplinas escolares podem possibilitar um entendimento que vai além da concepção dos conteúdos ensinados, chegando à compreensão de uma cultura escolar relativa a determinados tempos e espaços.

Segundo Chervel (1990), o termo "disciplina", aplicado à educação, surgiu na segunda metade do século XIX, associado ao verbo disciplinar, ou seja, buscava-se desenvolver um exercício intelectual, capaz de conduzir o aprendizado dos alunos. Contudo, logo após a Primeira Guerra Mundial, disciplina "torna-se uma pura e simples rubrica que classifica as matérias de ensino" (p. 180). Com isso, os conteúdos de ensino tornam-se um elemento específico da classe escolar, independentes, numa certa medida, de toda realidade cultural exterior à escola.

As disciplinas escolares são "organismos vivos, que nascem e se desenvolvem, evoluem, se transformam e desaparecem" (Viñao, 2008, p. 204) e segundo ele, podem ao mesmo tempo serem consideradas como um campo de disputa de poder social e acadêmico.

A produção dos pesquisadores que se voltam à história das disciplinas escolares, pautadas em tal base teórico-metodológica, representa uma tentativa de fornecer subsídios para o estudo das culturas escolares numa perspectiva histórica. Julia (2001) indica que "esta cultura escolar não pode ser estudada sem a análise das relações conflituosas ou pacíficas que ela mantém, a cada período de sua história, com o conjunto das culturas que lhes são contemporâneas" (p. 10). Assim, as práticas escolares são modificadas e inovadas, conforme as alterações do público e as necessidades socioculturais, que impõem a mudança dos conteúdos a serem ensinados.

Em relação à análise historiográfica que toma como principais fontes os livros didáticos, Choppin (2004) esclarece que

a concepção de um livro didático inscreve-se em um ambiente pedagógico específico e
em um contexto regulador que, juntamente com o desenvolvimento dos sistemas
nacionais ou regionais, é, na maioria das vezes, característico das produções escolares
(edições estatais, procedimentos de aprovação prévia, liberdade de produção, etc.). Sua
elaboração (documentação, escrita, paginação, etc.), realização material (composição,
impressão, encadernação, etc.), comercialização e distribuição supõem formas de
financiamento vultuosos, quer sejam públicas ou privadas, e o recurso a técnicas e equipes
de trabalho cada vez mais especializadas, portanto, cada vez mais numerosas. (p. 554)

$\mathrm{Na}$ medida em que o livro didático é considerado um instrumento pedagógico “inscrito em uma longa tradição, inseparável tanto na sua elaboração como na sua utilização das estruturas dos métodos e das condições do ensino de seu tempo" (Bittencourt, 1993, p. 3), 
DOI: https://doi.org/ 10.20396/zet.v27i0.8654072

isso nos faz refletir que o livro didático pode conter diversas formas de técnicas de aprendizagem: exercícios, questionários, sugestões de trabalho, enfim as tarefas que os alunos devem desempenhar para a apreensão ou, na maior parte das vezes, para a retenção dos conteúdos.

Ao pesquisador das disciplinas escolares que opte por utilizar os livros didáticos como fonte para seu trabalho cabe a busca de tais manuais inovadores e dos que, por algum aspecto, geraram a vulgata do período a que está se propondo a analisar. (Villela, 2009, p. 47)

Ao fazer parte da cultura escolar, o livro didático é organizado, veiculado e utilizado com certa intencionalidade, já que se vincula a uma cultura social mais ampla. Por isso, esse tipo de material serve como instrumento de mediação que a escola coloca entre a sociedade e os sujeitos em formação, o que significa interpretar sua função social.

Desenvolver uma pesquisa sobre livros didáticos do ponto de vista de um historiador das disciplinas escolares envolve localizá-los em todo um contexto histórico-cultural. É muito mais do que analisar conteúdos e propostas didático-metodológicas. É também preocuparse em percebê-los em um tempo e espaço determinados; tecê-los ao contexto em que foram produzidos; identificar similitudes e diferenças em relação a outros materiais didáticos do universo de então e dimensionar o seu papel nas culturas escolares em que foram veiculados. Para isso é preciso, a partir do presente, buscar pistas que nos façam desvendar a parte do passado que serviu de atmosfera à sua criação. (Villela, 2010, pp. 23)

Ao pensarmos no livro didático como fonte de pesquisa, mantemos a fundamentação deixada por Choppin (2004), para quem "a pesquisa histórica sobre os livros e as edições didáticas aborda aspectos extremamente diversos" (p. 554). É essa diversidade de aspectos observados em pesquisas que envolvem estes tipos de fontes que nos permite observar que "o livro didático deve ser considerado como veículo portador de um sistema de valores, de uma ideologia, de uma cultura" (Bittencourt, 1993, p. 3). Enfim, é preciso perceber que o livro escolar vai além de um depósito de conteúdos de naturezas diversas, que servem de guia pedagógico para alunos e professores.

Isso posto, é plenamente justificável fundamentar pesquisas sobre história da educação e, em especial, história da educação matemática. Assim sendo, este estudo procura compreender o contexto do método intuitivo no Brasil, nas últimas décadas do século XIX, em especial na obra Arithmetica Primaria, de Antonio Bandeira Trajano. Consequentemente visa levantar indícios sobre outras ações que deflagraram a implantação de tal método no ensino brasileiro de Aritmética.

\section{O método intuitivo}

De acordo com Franco Cambi (1999), o século XIX foi o século da pedagogia, momento emblemático da luta de classes (entre burguesia e proletariado), que envolveu sociedade, cultura, economia e política. Esse contexto acarretou uma radicalização das ideias 
DOI: https://doi.org/ 10.20396/zet.v27i0.8654072

pedagógicas e educativas, consolidando-as como ferramentas de controle social e do "projeto político e da própria gestão do poder (social e político)” (p. 407).

Com a revolução industrial e o desenvolvimento econômico e social decorrente do seu surgimento, iniciou-se uma mobilização social que aperfeiçoou o perfil das burguesias, dentre os seus grupos variados. Essas transformações, ocorridas numa sociedade econômica e politicamente turbulenta, estão ideologicamente presentes também na sua cultura. Nesse cenário, o ato de educar se tornara um mecanismo de controle (para a burguesia) e de emancipação social (para o povo).

No campo da educação, esse atrito entre classes deu vazão ao surgimento de pedagogias diferenciadas, com modelos e orientações diversas, e sempre altamente imbuídas de todas as vertentes e as etapas vividas ao longo do século XIX. E é nesse âmbito que a ideia de liberdade, defendida por pensadores como Pestalozzi ${ }^{3}$ e Fröebel ${ }^{4}$, se torna o indicador sociopolítico e, por conseguinte, ideológico da educação.

Também em meados do século XIX, o método intuitivo foi entendido por seus propositores europeus como um instrumento pedagógico capaz de reverter possível ineficiência existente no ensino escolar. Fundamentava-se na abordagem pela qual o ensino deve partir do simples para o complexo, do conhecido para o desconhecido, do concreto para o abstrato.

Intueri, intuitus significa olhar, observar. Estas duas palavras sintetizam o significado do novo método de ensino, que foi alçado pelos organizadores dos sistemas nacionais de ensino europeus e norte-americanos à principal saída para a criação de uma escola primária popular, alicerçada nos princípios da gratuidade, obrigatoriedade, secularização, liberdade e higienização, considerados signos do progresso e da modernidade pedagógica. (Auras, 2005, p. 133)

O destaque dado pelo método de ensino intuitivo ao empírico, à observação direta, ao ver, sentir e tocar era, pois, alicerçado no pressuposto de que o conhecimento tem início na operação dos sentidos sobre o mundo exterior, a partir dos quais seriam produzidas sensações e percepções, sobre fatos e objetos, transformadas em matérias-primas das ideias, as quais, acrescidas da imaginação e do raciocínio, possibilitariam o desenvolvimento da capacidade de julgamento e de discernimento.

Pode-se dizer que, em meados do século XIX, essa concepção sobre o conhecimento encontra-se tacitamente aceita em larga escala e é disseminada, perdendo-se de vista sua origem filosófica. A literatura pedagógica, por exemplo, não menciona os filósofos elaboradores desse ideário, mas faz uso, até mesmo indiscriminado, de suas proposições. Sucessivos pedagogos, como Pestalozzi e Fröebel, vão realizar experiências educacionais inovadoras, com o intuito de renovar as práticas pedagógicas, fazendo da educação dos

\footnotetext{
${ }^{3}$ Joham Heinrich Pestalozzi (1746-1827), educador suíço, entendia que os sentidos da criança, por meio dos quais ela conhece o mundo e a si mesma, eram importantíssimos para sua aprendizagem.

${ }^{4}$ Friedrich Wilhelm August Fröebel (1782-1852) foi um pedagogo alemão, com raízes na escola de Pestalozzi. Foi o fundador do primeiro jardim de infância, e o primeiro educador a enfatizar o brinquedo, a atividade lúdica, a apreender o significado da família nas relações humanas.
} 
DOI: https://doi.org/ 10.20396/zet.v27i0.8654072

sentidos seu objetivo mais importante. Manacorda (1989) afirma que os filósofos do século XVIII enfrentaram a difícil tarefa da sistematização teórica e política das conquistas burguesas nascentes e que os autores do século XIX vão enfrentar a difícil tarefa de colocá-las em prática. Esta dificuldade consiste justamente na transformação de princípios filosóficos em diretrizes para a prática de ensino, enfrentando um fato novo e determinante: a disseminação de escolas, a escolarização da instrução. Trata-se de transferir para indivíduos reais - crianças - proposições abstratas elaboradas sobre indivíduos genéricos. É justamente nessa tentativa que é elaborado e torna-se uma corrente bastante vigorosa na educação o método de ensino intuitivo, caminho metódico para a educação dos sentidos e para a educação e pela experiência. (Valdemarim, 2004, p. 39)

Neste ponto, é conveniente lembrarmos que:

O método de ensino é apresentado como recurso pedagógico capaz de atender às demandas da sociedade, formando indivíduos portadores das habilidades básicas, como ler, escrever, calcular, e que valoriza o progresso científico e industrial de modo a dar-lhe prosseguimento por meio da formação escolar. (Valdemarin, 2010, p. 21)

Portanto, podemos retomar as ideias do método de ensino intuitivo, através dos estudos de Valdemarin (2004), os quais afirmam que esse método "é entendido como um instrumento pedagógico capaz de reverter a ineficiência do ensino escolar" (p. 103). A potencialidade atribuída a esse método de ensino "pretende direcionar o desenvolvimento da criança de modo que a observação gere o raciocínio, e o trabalho prepare o futuro produtor, tornando indissociáveis pensar e construir" (p. 103).

Essa autora também comenta que

a introdução dos objetos didáticos na educação tem um caráter lúdico, mas também disciplinador: um elemento novo em sala de aula torna-se o centro da atenção das crianças, instaurando assim algo que é comum a toda a classe de alunos e ao professor, é aquilo que os une no caminho do conhecimento. (p. 176)

Ao que tudo indica, o método intuitivo, dada sua pretensão de constituir-se a base para a modernização da forma de ensinar, apresentava-se como uma possível alternativa ao caráter abstrato e pouco utilitário da instrução. Vinha em resposta a um descontentamento generalizado com o ensino, o qual estava expresso em diversos meios de comunicação, desde a primeira metade do século XIX. A este tempo escolar, o sistema de ensino era considerado ineficiente, com alunos sendo formados sem domínio da leitura e da escrita e com noções rudimentares de cálculo. Acreditava-se que o problema estava no fato de a aprendizagem ser fundamentada exclusivamente na memória, exigindo um grau elevado de abstração, valorizando a repetição ao invés da compreensão, impondo o conteúdo sem a participação efetiva do aluno. Somava-se a essas medidas o desenvolvimento econômico que necessitava de cidadãos capazes de raciocinar rápido e criativamente. Valdemarim (2004) conta que

nesse clima de descontentamento generalizado, expresso em enquetes, documentos oficiais e pareceres, o movimento de renovação pedagógica que começou a despontar na metade do século XIX tenta investir contra o caráter abstrato e pouco utilitário da instrução, prescrevendo-lhe novo método de ensino, novos materiais, a criação de museus pedagógicos, variação de atividades, excursões pedagógicas, estudo do meio, entre outras. $\mathrm{O}$ raio de abrangência desse movimento pode ser avaliado também pelas sucessivas 
DOI: https://doi.org/ 10.20396/zet.v27i0.8654072

exposições universais, organizadas para a difusão de práticas pedagógicas renovadas, seus materiais e suas aplicações: Londres em 1862, Paris em 1867, Viena 1873, Filadélfia em 1876, que deram origem ao Relatório de Buisson, países que se inserem no mesmo modo de produção e de circulação de mercadorias, embora com resultados e competências diversas. (p. 104)

Este método consistia na colocação de fatos e objetos a serem observados pelos alunos, a partir do que o conhecimento iria emergir no entendimento da criança com os dados fornecidos pelo próprio objeto. A intuição a ser utilizada na educação, a nosso ver, é a capacidade de ver, de observar.

O "método objetivo" ou "intuitivo", de ensinar a ler principia, dirigindo a atenção dos alunos para algum objeto, cujo aspecto, nome e uso lhes sejam familiares. Sempre que exequível for, nas primeiras lições de leitura, se mostrará o objeto, discorrendo a seu respeito, e proferindo-lhe o nome; após o que exibirá o mestre uma estampa desse objeto, ou o desenhará no quadro preto, induzindo os alunos a notarem como essa é a imagem ou pintura dele. Em seguida se lhe imprimirá por inteiro o nome no quadro preto, ou apresentará impresso numa carta ou mapa. Então aprenderá o discípulo a distinguir o objeto, a sua imagem palavra que nomeia; assim, por exemplo: "a xícara, a imagem da xícara, a palavra xícara". Destarte podem-se ensinar muitos vocábulos, antes de se estrearem os sons ou letras de cada um. (Barbosa, 1950, p. 422)

Como percebemos, este método se configurava como instrumento pedagógico capaz de reverter a ineficiência do ensino escolar, não somente no aspecto metodológico, mas também na sua função para a política e para a estabilização do regime republicano, pois o discente não estaria sendo preparado apenas para ler e escrever, mas, sim, para ter uma interpretação aguçada das situações e das coisas que lhe pareciam comuns no seu cotidiano.

Ao que parece, o grande argumento estava na defesa do papel ativo do aluno na busca da compreensão dos fatos e dos conhecimentos. Isso não significava que o professor não desempenhasse um papel importante em sala de aula, e nem que não fosse mais necessário à escola.

A observação esmiuçadora das coisas e dos objetos permitia que o aluno fizesse uma transposição do conhecimento sensível para a elaboração mental dos conhecimentos. Iniciava-se, assim, o estudo pelas lições de coisas, momento em que o educador deveria proporcionar as condições adequadas para que os educandos pudessem sentir, manipular e observar os objetos. Assim sendo, o professor assumia o papel de direcionador e sistematizador das atividades que os alunos iriam desenvolver, as quais seriam responsáveis pela elaboração mental dos seus conhecimentos.

\section{O método intuitivo no Brasil}

Na segunda metade do século XIX, várias reformas tentaram dar um rumo mais profícuo à Educação. Segundo Aranha (1996), no ano de 1867, só cerca de $10 \%$ da população em idade escolar estava matriculada e, em 1890, no início da República, a taxa de analfabetismo chegava a $67,2 \%$. Este cenário pode ter levado à implantação de vários 
DOI: https://doi.org/ 10.20396/zet.v27i0.8654072

métodos de ensino no Brasil, dentre eles o intuitivo, que propunham a exploração dos cinco sentidos para auxiliar o aprendizado.

Para realizarmos um breve mapeamento sobre a penetração do método intuitivo no Brasil, vejamos os informes sobre o que estava sendo realizado no Instituto dos SurdosMudos, no Rio de Janeiro. Por exemplo, no relatório publicado em 1870, o diretor Tobias Rabello Leite citava que, no ano anterior, "primeiro anno de existência regular do Instituto", tinham tomado a iniciativa de publicar o livro Lições de Arithmetica Pratica, do professor Magalhães Couto, e de traduzir o "Cattecismo do abbade Lambert ... por conter a aplicação ao methodo intuitivo ao ensino religioso" e a "Grammatica pratica de Chambellan, ... modelado sobre o methodo intuitivo com as modificações exigidas pela nossa lingua e pelos nossos costumes" (Leite, 1870, p. 2).

Essa concepção de ensino também já circulava por outras instituições: a proposta de trabalho do Colégio Internacional de Campinas, "dirigido pelos Srs. G. Nasch Morton e Ed. Lane" foi comentada no jornal A Patria (anno XVIII, n. 10, 6/8/1874, pp. 2-3). No Rio de Janeiro, o Colégio Menezes Vieira já se considerava usuário do método intuitivo em 1875 , como mostra a Figura 1.

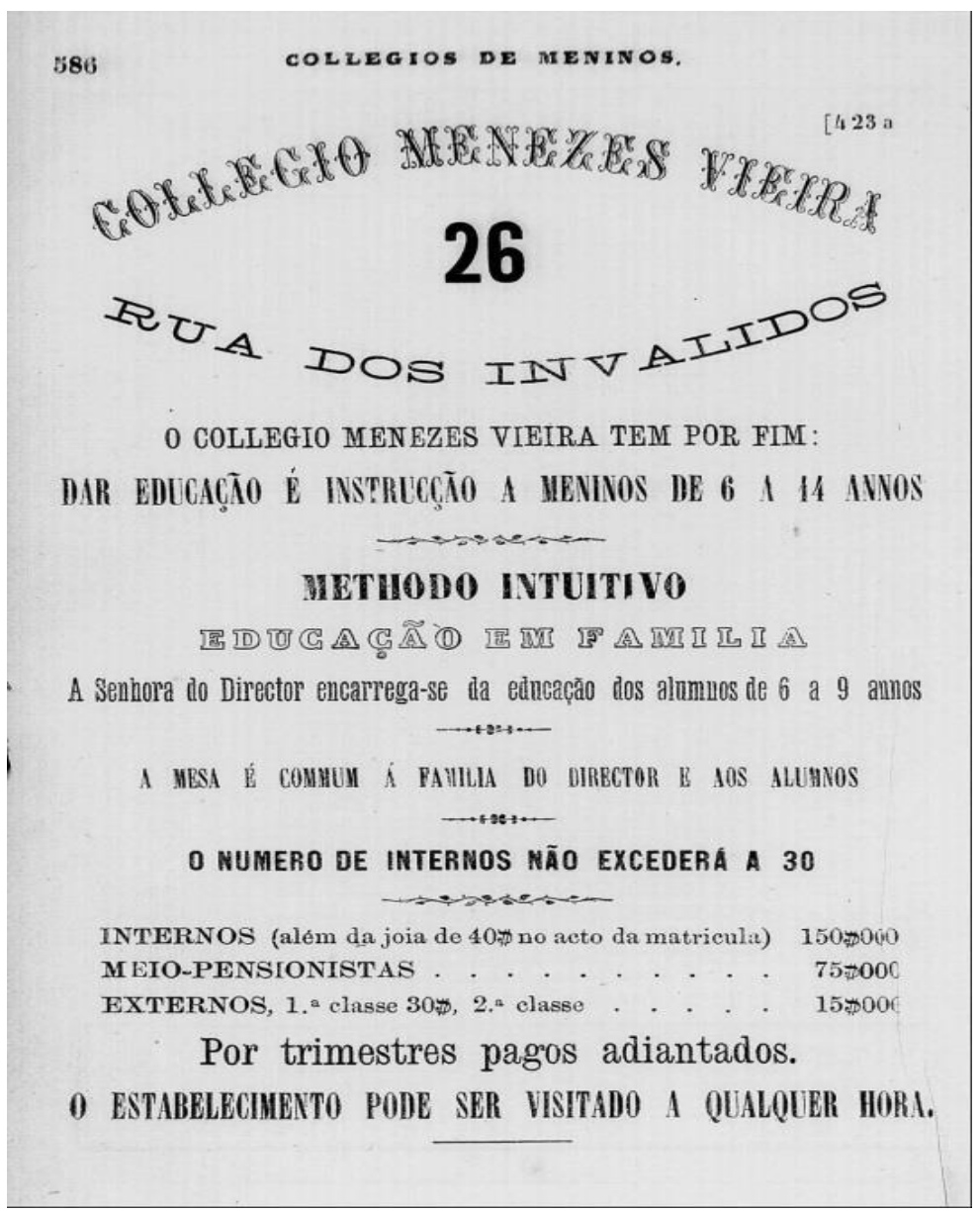

Figura 1 - Almanak administrativo, mercantil e industrial da Côrte e da Província do Rio de Janeiro Fonte: Carneiro (2014, p. 28) 
DOI: https://doi.org/ 10.20396/zet.v27i0.8654072

Essas notícias não circulavam apenas no eixo Rio-São Paulo. Como, por exemplo, a tradução do artigo "Lição de Cousas", republicada em três números do jornal $A$ Constituição, em Belém do Pará, em novembro de 1876, com a tradução do que saíra no Diário de Pernambuco. Ou a publicação da resenha traduzida do livro Lição de Cousas, segundo $M .^{m m}$ M. Pape Carpentier ${ }^{6}$, em três números do periódico Publicador Maranhense, em dezembro de 1878.

Esses vestígios encontrados indicam que na "Reforma do ensino primário e secundário no município da Corte e o superior em todo o Império" (Decreto n. ${ }^{\circ}$ 7.247, de 19 de abril de 1879), assinada por Carlos Leôncio de Carvalho e que regulamentava a instrução primária e secundária do município da Corte, não causaria estranheza a recomendação de que se usasse a "pratica do ensino intuitivo ou lições de cousas" na formação de professores na Escola Normal.

Art. $9^{\circ} \mathrm{O}$ ensino nas Escolas Normaes do Estado comprehenderá as disciplinas mencionadas nos dous primeiros paragraphos seguintes:

$\S 1^{\circ}$ Lingua nacional. Lingua franceza. Arithmetica, algebra e geometria. Metrologia e escripturação mercantil. Geographia e cosmographia. Historia universal. Historia e geographia do Brazil. Elementos de sciencias physicas e naturaes, e de physiologia e hygiene. Philosophia. Principios de direito natural e de direito publico, com explicação da Constituição politica do Imperio. Principios de economia politica. Noções de economia domestica (para as alumnas). Pedagogia e pratica do ensino primario em geral. Pratica do ensino intuitivo ou lições de cousas. Principios de lavoura e horticultura. Calligraphia e desenho linear. Musica vocal. Gymnastica. Pratica manual de officios (para os alumnos). Trabalhos de agulha (para as alumnas). Instrucção religiosa (não obrigatoria para os acatholicos). (Decreto n. ${ }^{\circ} 7.247$, de 19 de abril de 1879)

De acordo com o artigo supracitado, o método do ensino intuitivo estava sendo mencionado como disciplina escolar. Para fazer um bom uso dele, utilizavam-se materiais pedagógicos que ficavam dispostos nas salas de aulas. Assim, esses materiais acabavam assumindo o papel de instrumentos auxiliadores de trabalho para o professor e, como meios da aquisição de conhecimento, para os alunos. Podemos verificar essa afirmação, ao examinar a seguinte fotografia (Figura 2), apresentada por Diana Gonçalves Vidal.

\footnotetext{
${ }^{5}$ Variedade: Lição de Cousas. Transcrição de artigo publicado no Diario de Pernambuco: Tradução de artigo Bulletin de Seine el Morne. A Constituição, Belem do Pará, anno III, n 247, 248 e 250, em 2, 3 e 6 de novembro de 1876. Retirado em 20 de junho de 2014, de http://memoria.bn.br/DocReader/DocReader.aspx?bib=385573 \&pesq=li\%C3\%A7\%C3\%A3o\%20de\%20cousas\&pasta=ano\%20187.

${ }^{6}$ Litteratura: Lição de cousas, segundo M.mm M. Pape Carpentier. Publicador Maranhense. Anno XXXVII, n. 282, 284 e 285, em 10, 12 e 13 de dezembro de 1878. Retirado em 18 de junho de2014, de http://memoria.bn.br/ DocReader/DocReader.aspx?bib=720089\&pesq=li\%C3\%A7\%C3\%A3o\%20de\%20cousas\&pasta=ano\% 20187 .
} 


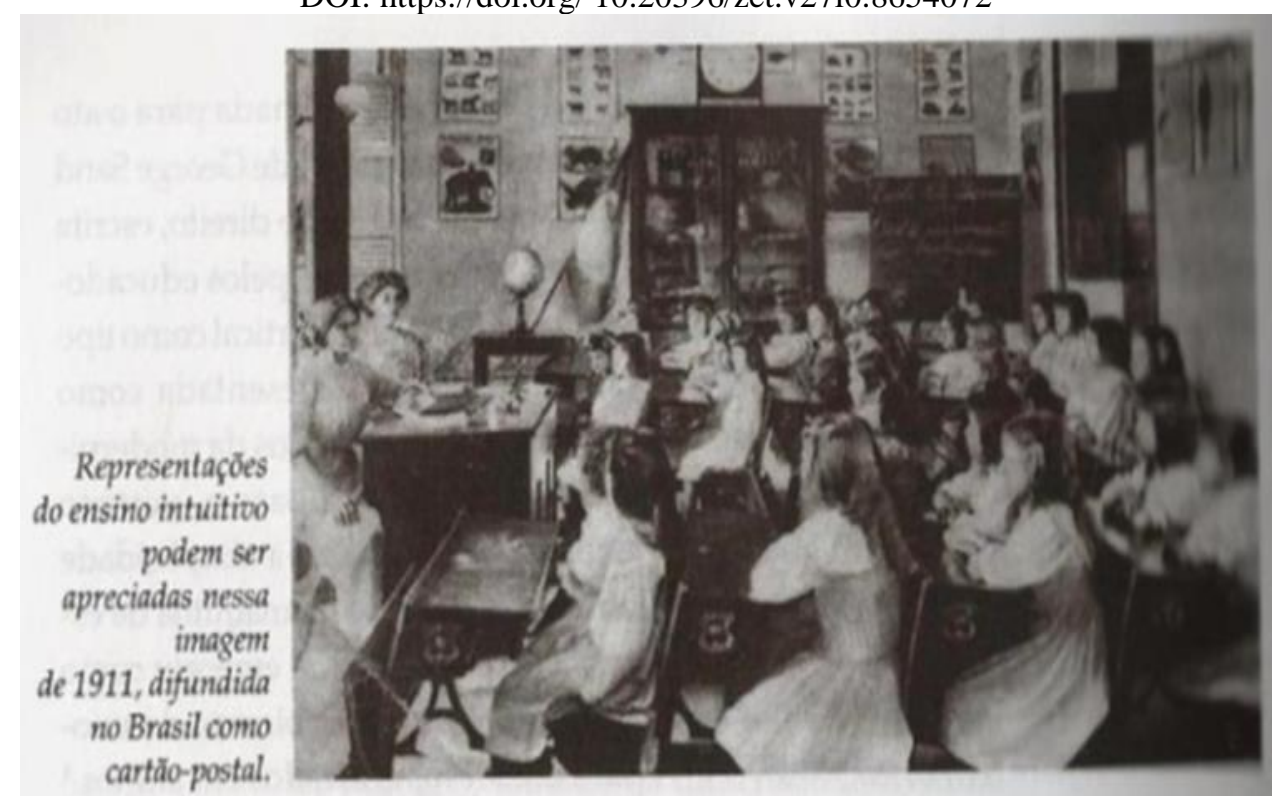

Figura 2 - Foto de uma sala de aula em um postal de 1911

Fonte: Vidal (2000, p. 500)

Nela podemos ver facilmente a representação do método de ensino intuitivo. A maneira como se encontram visíveis alguns dos materiais necessários para fazer bom uso dos princípios deste método, como mapas, cartazes, coleções de insetos, globo terrestre, dentre outros. Assim, os sentidos também poderiam ser utilizados em objetos escolares como carteira, quadro-negro, pedras, madeiras, mapas, cartazes, entre outros; ou poderiam ser realizados passeios fora da sala de aula com a intenção de manter contanto com a natureza.

\section{Trajano e sua Arithmetica Primaria}

Nascido em 30 de agosto de 1843, na cidade de Vila Pouca de Aguiar, Portugal, Antonio Bandeira Trajano iniciou a vida escolar em uma escola primária local e aos 12, frequentou uma escola de ensino secundário em Guimarães. De acordo com Matos (2004, p. 315), chegou ao Brasil em 1857, quando tinha 14 anos, tornando-se brasileiro por naturalização. Trabalhou em uma casa comercial no centro velho de São Paulo. Em 1865, tornou-se um dos membros fundadores da Igreja Presbiteriana de São Paulo, passando a fazer parte dos colportores, que distribuíam bíblias e literatura evangélica nas províncias de São Paulo e Minas Gerais.

Dois anos depois, em 1867, ingressou no seminário fundado no Rio de Janeiro e, como seminarista, lecionou Geografia e Aritmética na escola paroquial anexa à igreja (Matos, 2004, p. 316). No período de setembro a dezembro de 1870, trabalhou em Borda da Mata, Minas Gerais.

Veio a ser ordenado pastor presbítero em 10 de agosto de 1875 , na cidade de Rio Claro, ficando encarregado das Igrejas Evangélicas Presbiterianas de Brotas, Rio Novo e Dois Córregos, todas no interior de São Paulo. Um ano depois, "no dia 10 de agosto de 1876, 
DOI: https://doi.org/ 10.20396/zet.v27i0.8654072

foi eleito o primeiro pastor nacional da Igreja do Rio de Janeiro, assumindo o cargo em 27 de novembro" (Matos, 2004, p. 317). Quando do falecimento de sua filha Guiomar, em agosto de 1877, foi lecionar Matemática em São Paulo, na Escola Americana, onde ficou até outubro de 1880, retornando ao "pastorado da Igreja do Rio, cargo que ocupou até abril de 1893" (p. 317). Nesse ano Trajano "foi para a Europa em busca de tratamento" (p. 317).

Embora afastado do pastorado por vários anos, Matos (2004) conta que ele continuava atuando nas pregações de domingo na Igreja do Rio, compartilhando momentos com seu exaluno da Escola Americana, além de ter assumido importante papel na disseminação do presbiterianismo no Brasil e do registro dessa parte da história. Em julho de 1902, foi jubilado pelo Presbitério do Rio de Janeiro e faleceu aos 78 anos no dia 23 de dezembro de 1921.

Arithmetica Primaria, de Trajano

O autor Antônio Bandeira Trajano fez no prefácio da 12. ${ }^{\text {a }}$ edição de sua Arithmetica Primaria, algumas críticas ao ensino de Aritmética praticado na época, no tocante, especialmente, aos livros adotados nas escolas, os quais considerava, em geral, condensados e inadequados.

Para ele, os outros autores não eram claros o suficiente e não apresentavam um desenvolvimento necessário para a compreensão do conteúdo. Ao invés disso, alguns traziam uma demonstração "feita com linhas geometricas ou com expressões algebricas". Alegava, ainda, que os livros, além de trazer exemplos sem nenhum atrativo para os estudantes, ainda eram despidos "inteiramente da pratica indispensável para exercitar o alumno no manejo do calculo" (Trajano, n.d, p. I).

Assim sendo, segundo o autor, surgiu daí a necessidade de elaborar livros didáticos para o ensino de Aritmética, pois, como ele dizia no prefácio da 12. ${ }^{a}$ edição, cuja capa está reproduzida na Figura 3: "precisamos de livros adequados à inteligência da infância e que não só ensine, mas também desenvolva nos meninos o gosto pela Arithmetica” (p. I-II). 


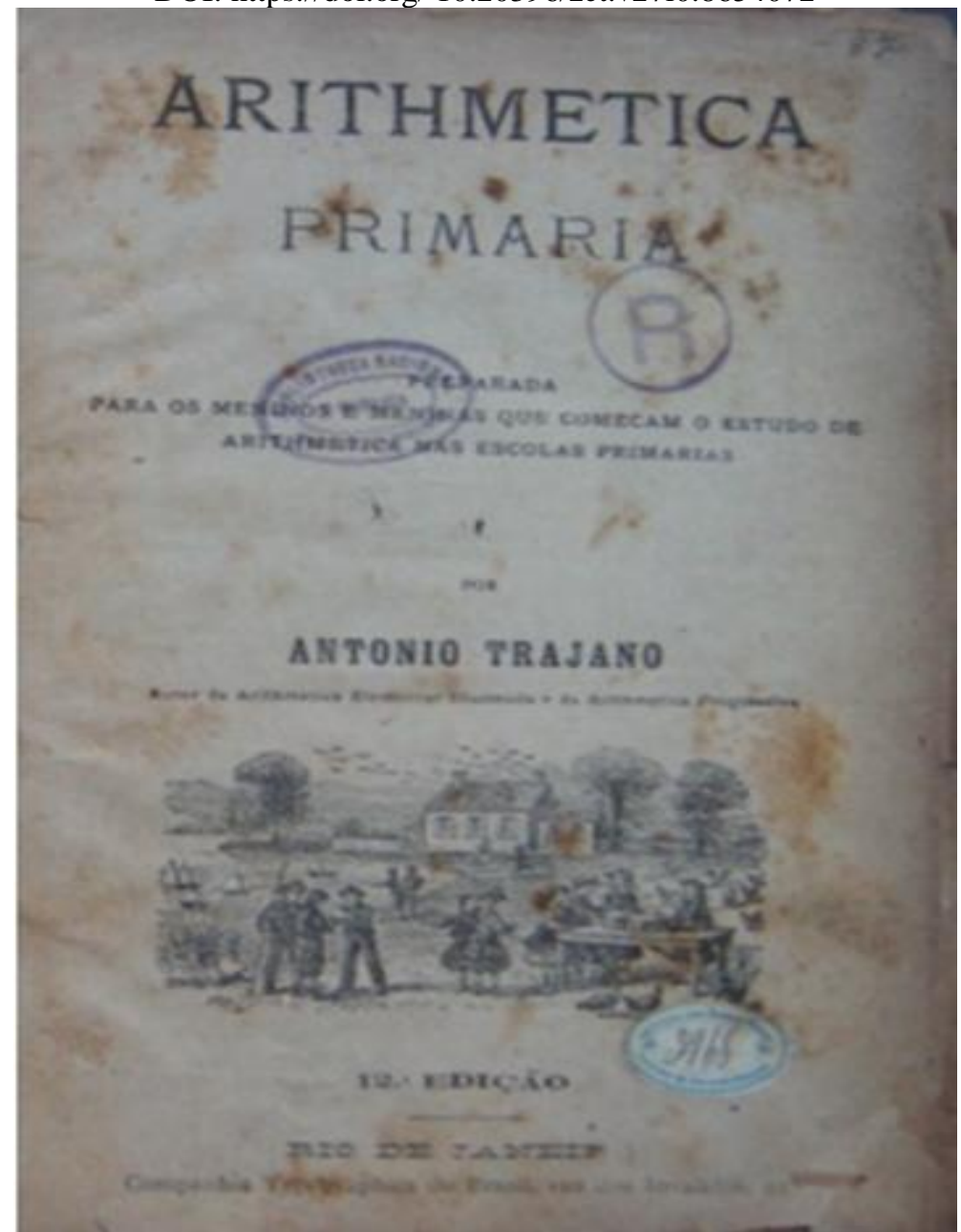

Figura 3 - Capa da 12. ${ }^{a}$ edição da Arithmetica Primaria, de Antônio Trajano Fonte: Carneiro (2014, p. 86)

Este livro está disponibilizado no Repositório do Grupo de Pesquisa de História da Educação Matemática $\left(\right.$ GHEMAT) ${ }^{7}$. A 12. ${ }^{a}$ edição foi editada pela Companhia Typografica do Brasil. Não possui sua data de edição, mas traz indícios que deva ter ocorrido entre 1874 a 1890. O que nos permitiu chegar a essas possíveis datas da 12. ${ }^{a}$ edição foi a presença do selo do "Instituto dos Surdos-Mudos officina de encadernação" (Figura 4), na sua capa, como nos alerta Nara Pinheiro (2013):

Ao longo de sua história este instituto teve várias denominações, mas apenas no período de 1874 a 1890 a denominação constante no referido selo. Além de oferecer instrução literária a seus alunos, o instituto oferecia aos surdos a oportunidade de aprenderem uma profissão na gráfica por ela mantida. Nas primeiras décadas da república o trabalho realizado na gráfica, pelos surdos, foi referência no Rio de Janeiro. Também nesta época a gráfica recebia encomendas de encadernação de quase todas as instituições públicas e particulares. (p. 47)

\footnotetext{
${ }^{7}$ http://repositorio.ufsc.br/handle/123456789/1769
} 


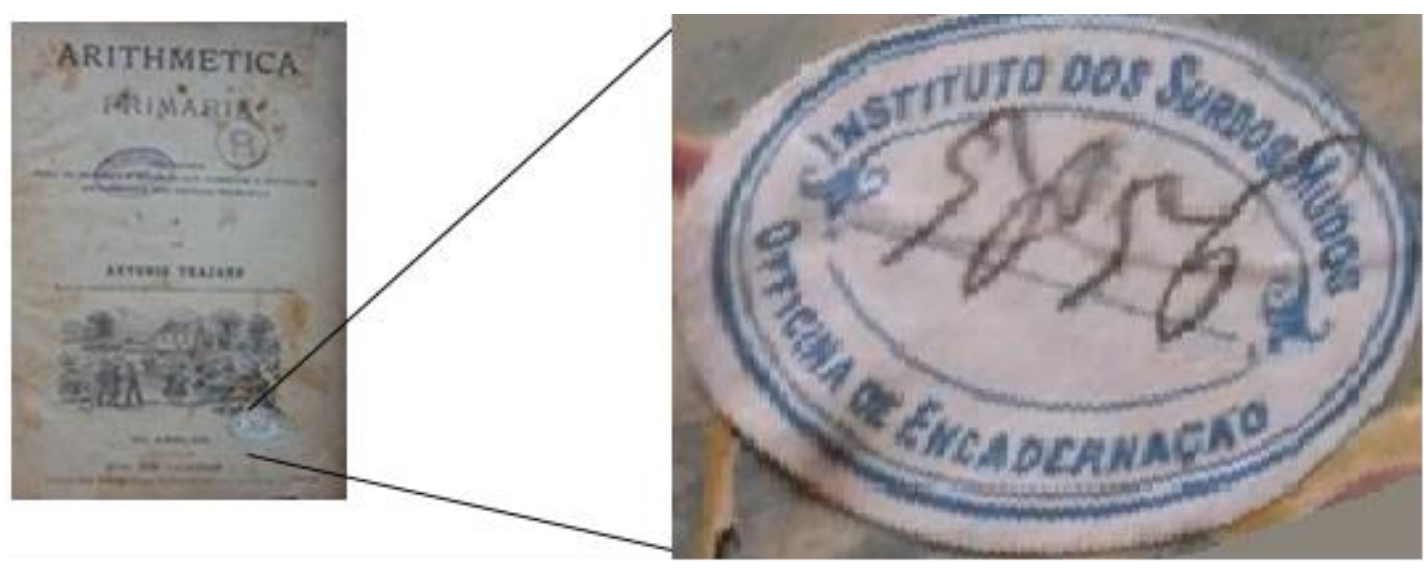

Figura 4 - Ampliação do selo do Instituto dos Surdos-Mudos (Officina de Encadernação) Fonte: Carneiro (2014, p. 87)

De acordo com o levantamento biográfico que fizemos sobre o autor, a primeira edição desse livro foi publicada quando Trajano estava na pastoral da Igreja do Rio de Janeiro. Este livro, segundo Trajano (n.d.), era "destinado aos meninos e meninas que começam o estudo de arithmetica nas escolas primarias" (p. 3). Uma de suas grandes preocupações, como professor, era de que os alunos poderiam estar saindo do ensino primário sem os conhecimentos básicos de Aritmética. Visualizava que isso poderia ocasionar um dano irreversível, pois "quando nas suas lidas e ocupações se veem na precisão de calcular, então reconhecem o seu atrazo e ignorância, e tambem como foi imprestável o ensino que receberam na escola" (p. 3).

É possível supor que, para Trajano, um dos prováveis motivos para o não aprendizado da Aritmética era a utilização de livros didáticos não adequados ao nível de ensino e a não utilização de um método de ensino que propiciasse ao aluno uma aprendizagem mais completa, tendo sido essas as justificativas para publicar a obra aqui analisada. Essa preocupação se confirma, quando o autor afirmava que:

O mal, porém, não vem somente dos livros, vem também do methodo do ensino nas escolas primarias. Alguns professores não ligam muita importância a este ramo de instrução; exigem que os alumnos decorem correctamente as definições e as regras, e que resolvam o exemplo que o compendio traz já resolvido, e limitam a esta aprendizagem o importante ensino da Arithmetica. E o que ficará sabendo o pobre alumno com um estudo tão superficial? (p. 04)

O seu livro tratava dos conteúdos com um método, que, para Trajano, era mais adequado ao ensino primário da Aritmética. Na 12. a edição da Arithmetica Primaria, Trajano abordou em suas 64 páginas a numeração (sobre "números arabicos, romanos e quantias"); as operações fundamentais ("sommar, subtrahir, multiplicar e dividir"); as propriedades dos números ("numeros primos, numeros multiplos, divisibilidade, minimo multiplo comum, maximo divisor comum"); "as fracções; as operações com fracções; as fracções decimais; 
DOI: https://doi.org/ 10.20396/zet.v27i0.8654072

systema métrico". Todos os conteúdos eram expostos em lições gradativas, ou seja, iam aumentando o grau de complexidade com o decorrer do estudo.

A obra se inicia por abordagem dos conteúdos pela numeração, que, segundo Trajano (n.d.) "é a parte da Arithmetica que ensina a ler os números e a escreve-los por meio de algarismos" (p. 7). Aqui o autor começa com os conceitos de ordens e classes, mas o que nos chamou a atenção foi a presença de uma figura (Figura 5) que exemplificava o que estava sendo explicado, tal como recomendado pelo método intuitivo.

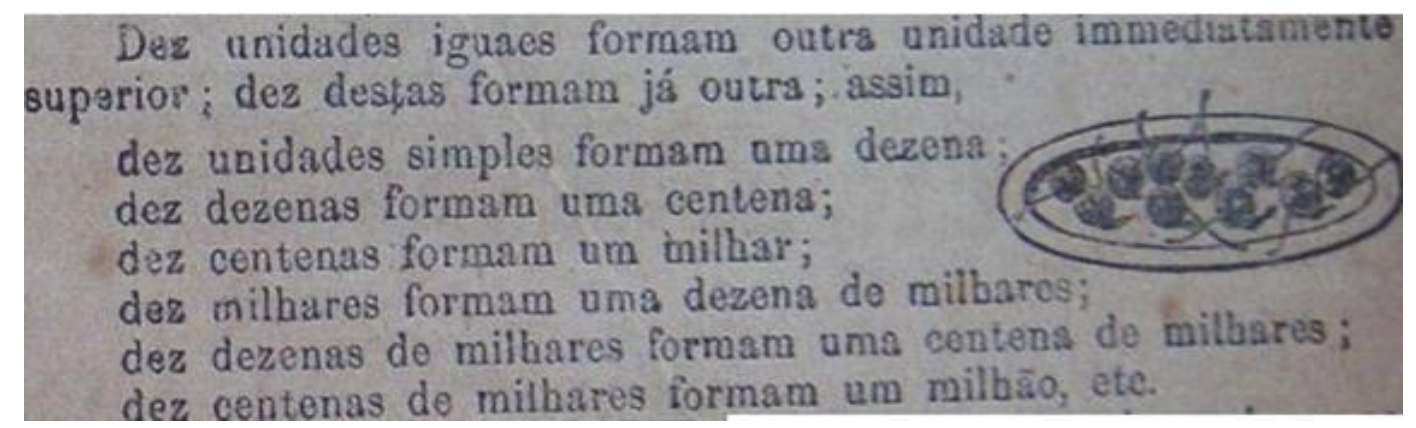

Figura 5 - Explicação sobre conceitos de ordens e classes

Fonte: Trajano (n.d., p. 7)

É visível a intenção de correlacionar as dez unidades que estão sendo abordadas na explicação, com as dez "cerejas" presentes na figura ao lado. Assim, os alunos estariam visualizando que estas dez unidades formam uma outra unidade maior: o prato de cerejas. Com isso, chega-se a explicação sobre a base do sistema de numeração decimal.

No início de cada conteúdo abordado pelo livro, o autor se reportou ao "ensino intuitivo da figura". Introduzia o que ia ser estudado, por meio da observação da figura, sem apresentar a conceituação e as regras, auxiliando, dessa maneira, os alunos a responderem os questionamentos iniciais. Vejamos, na Figura 6, como o autor começava a operação "sommar". 
DOI: https://doi.org/ 10.20396/zet.v27i0.8654072

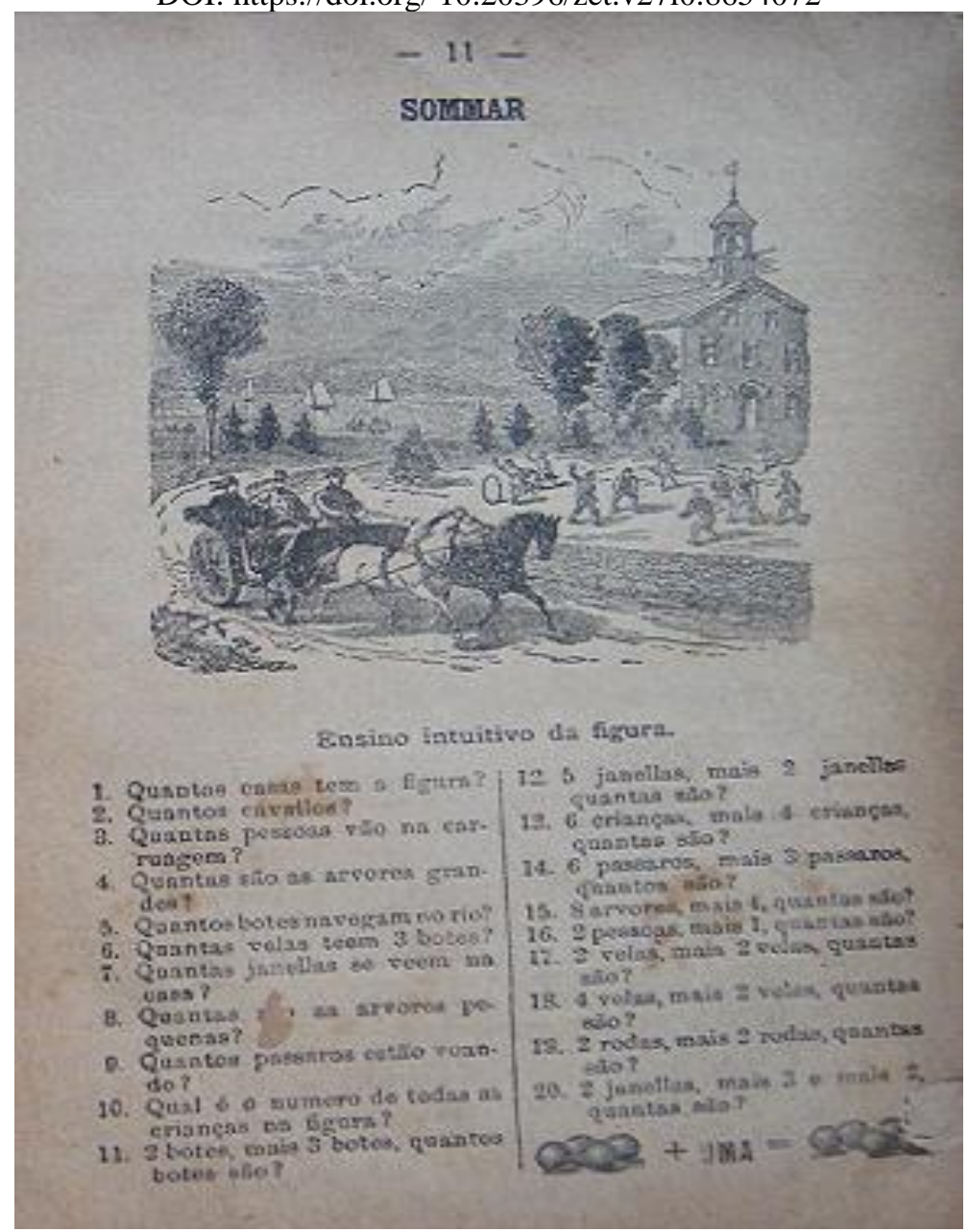

Figura 6 - Ilustração do ensino intuitivo da figura ${ }^{8}$

Fonte: Carneiro (2014, p. 91)

Como podemos observar, a figura foi explorada por meio de 20 perguntas, que poderiam ser respondidas com a sua observação, e que remetiam ao início do aprendizado da adição através da contagem. O grau de dificuldade das questões era crescente, de forma que, nas primeiras, o aluno precisaria de uma breve análise da imagem para respondê-las, enquanto nas últimas, além da contextualização com alguns elementos que estavam na figura, exigia-se um raciocínio mais articulado para obtenção das soluções, como, por exemplo, a questão 19, em que se visualizavam só as duas rodas da carroça presentes na figura.

Antônio Trajano apresentou o ensino deste conteúdo em oito lições. Na primeira, ele fez uma junção entre o modo mais clássico de se tratar a adição e o método intuitivo (a

\footnotetext{
8 Transcrição das questões que estão na Figura 6: 1. Quantas casas tem a figura? 2. Quantos cavalos? 3. Quantas pessoas vão na carruagem? 4. Quantas são as árvores grandes? 5. Quantos botes navegam no rio? 6. Quantas velas tem 3 botes? 7. Quantas janelas se veem na casa? 8. Quantas são os as árvores pequenas? 9. Quantos pássaros estão voando? 10. Qual é o número de todas as crianças na figura? 11. 2 botes, mais 3 botes, quantos botes são? 12. 5 janellas, mais 2 janellas quantas são? 13. 6 crianças, mais 4 crianças quantas são? 14.6 pássaros, mais 3 pássaros quantos são? 15.8 árvores, mais 4, quantas são? 16. 2 pessoas, mais 1, quantas são? 17. 2 velas, mais 2 velas, quantas são? 18. 4 velas, mais 2 velas, quantas são? 19. 2 rodas, mais duas rodas, quantas são? 20. 2 janellas, mais 3 e mais 2, quantas são?
} 
DOI: https://doi.org/ 10.20396/zet.v27i0.8654072

observação de figuras). De maneira mais tradicional, tinham-se a definição, a apresentação dos termos que compunham a adição, a simbologia utilizada e, de modo intuitivo, a operação era apresentada via problemas, resolvidos por meio de desenhos. Como o ensino estava fundamentado na observação, tornava-se importante que as crianças visualizassem o problema por meio de ilustrações, como pode ser percebido na Figura 7.

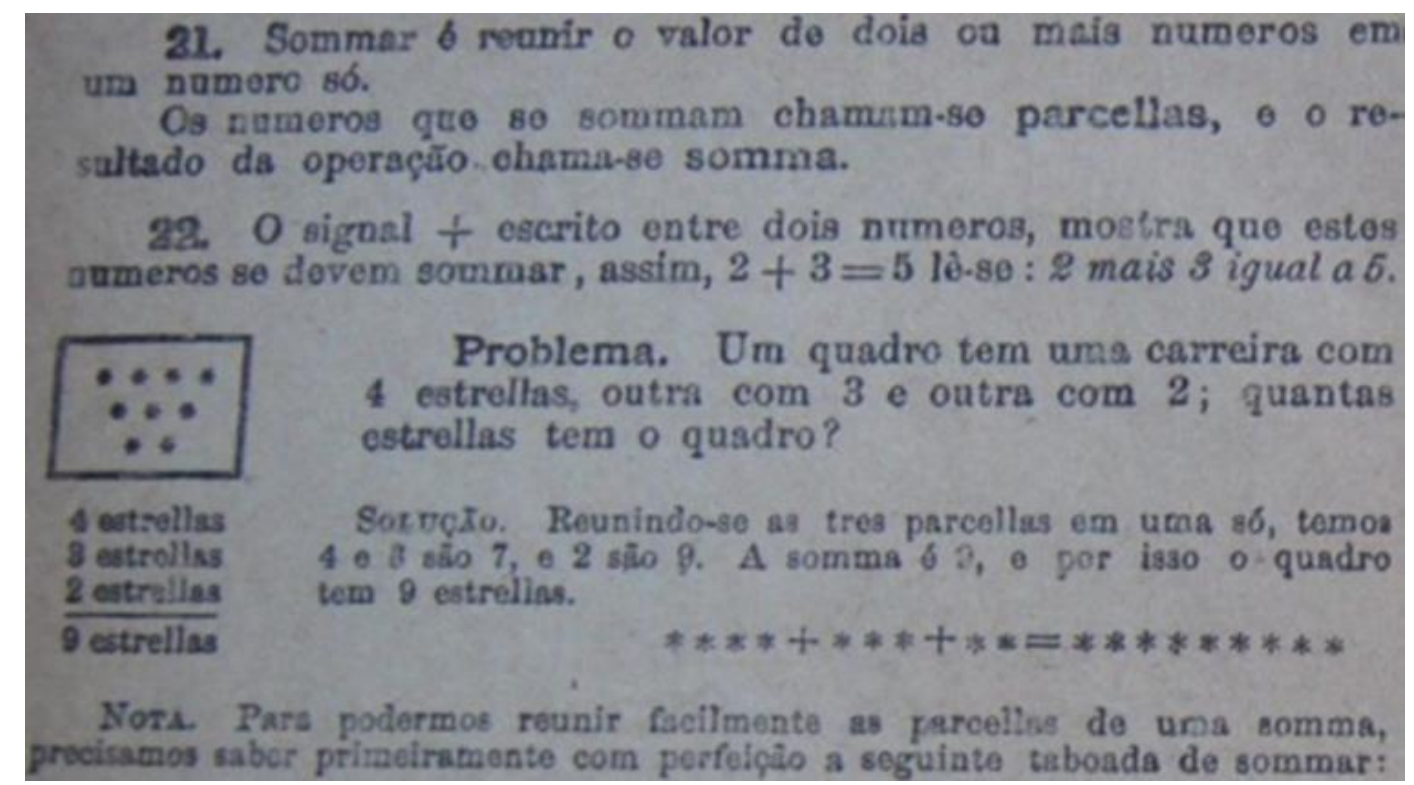

Figura 7 - Primeira lição de Sommar e Modelo de problema resolvido por meio de ilustrações Fonte: Trajano (n.d., p. 12)

Como podemos observar na Figura 8, o autor reforçava que a facilidade de se reunirem parcelas poderia ser adquirida quando o aluno soubesse com perfeição a "tabuada de sommar". Posteriormente, a abordagem continuava nas demais lições de "Sommar".

Esse encaminhamento se repetia nas outras três operações, fundamentais da Aritmética.

Assim, após a introdução pelo "ensino intuitivo da figura" e dos problemas resolvidos por meio da ilustração, vemos nesta 12. ${ }^{\text {a }}$ edição da Arithmetica Primaria, de Antônio Trajano, lições que propunham a abordagem tanto mais prática, como algumas mecânicas.

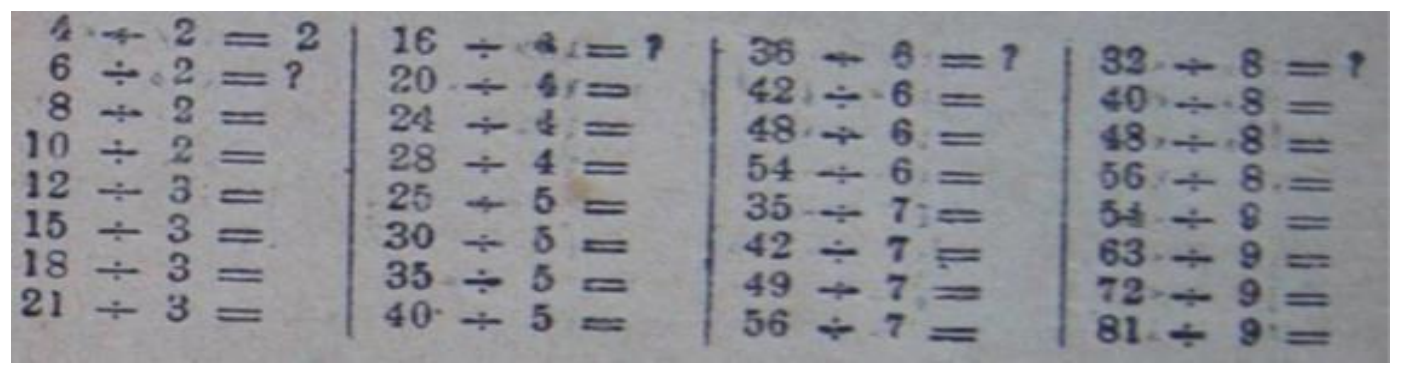

Figura 8 - Segunda Lição de Dividir

Fonte: Trajano (n.d., p. 31)

A "segunda lição de dividir", mostrada na Figura 8, evidencia uma abordagem mais mecânica do ensino, pois o aluno era apenas desafiado a dar o resultado da operação. Mesmo 
DOI: https://doi.org/ 10.20396/zet.v27i0.8654072

com a defesa que o autor fazia de que os livros deveriam ser atrativos para os estudantes, ele também apresentava o mecanismo para a fixação dos conteúdos abordados no livro.

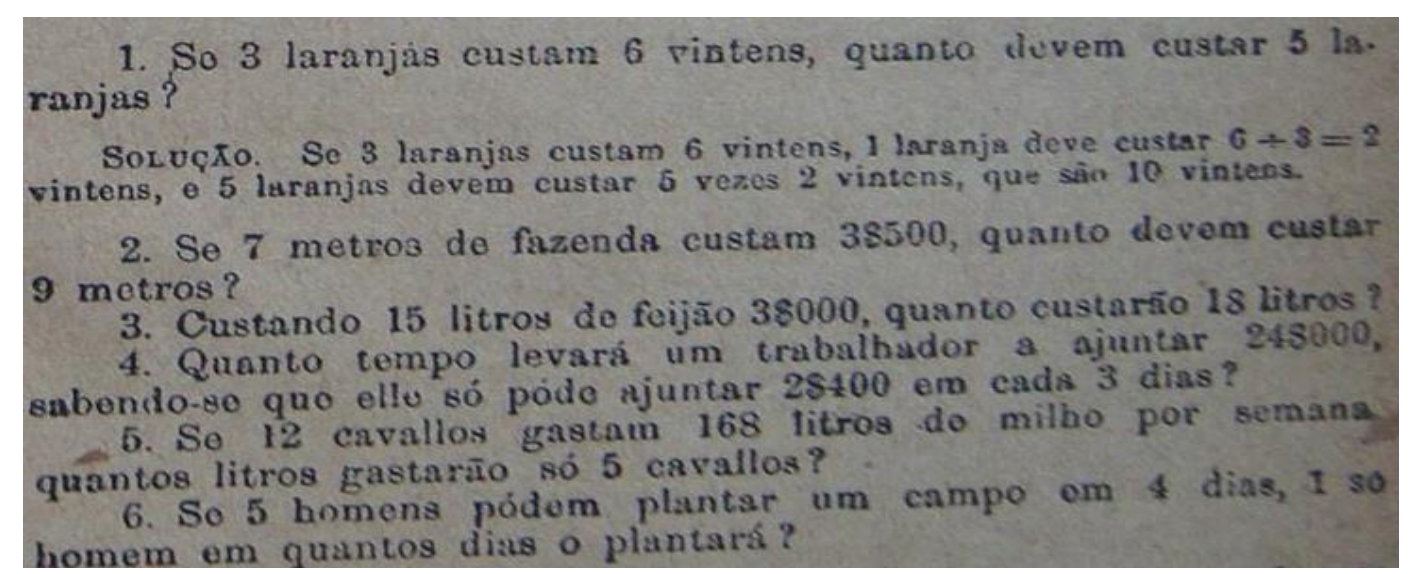

Figura 9 - Décima segunda Lição sobre as quatro operações

Fonte: Trajano (n.d., p. 35)

Já nesse fragmento da décima segunda lição sobre as quatro operações (Figura 9), constatamos uma linguagem mais prática, pois os alunos eram convidados a visualizar uma situação que poderia ocorrer no cotidiano e interpretá-la para, posteriormente, vir a desenvolver a operação aritmética necessária.

Observamos uma linguagem mais técnica com definições, regras e exercícios nos demais conteúdos abordados neste livro, especialmente no trato dos critérios de divisibilidade (Figura 10), assim como nos demais conteúdos: mínimo múltiplo comum, máximo divisor comum, fracções, operações com fracções, fracções decimais e systema métrico.

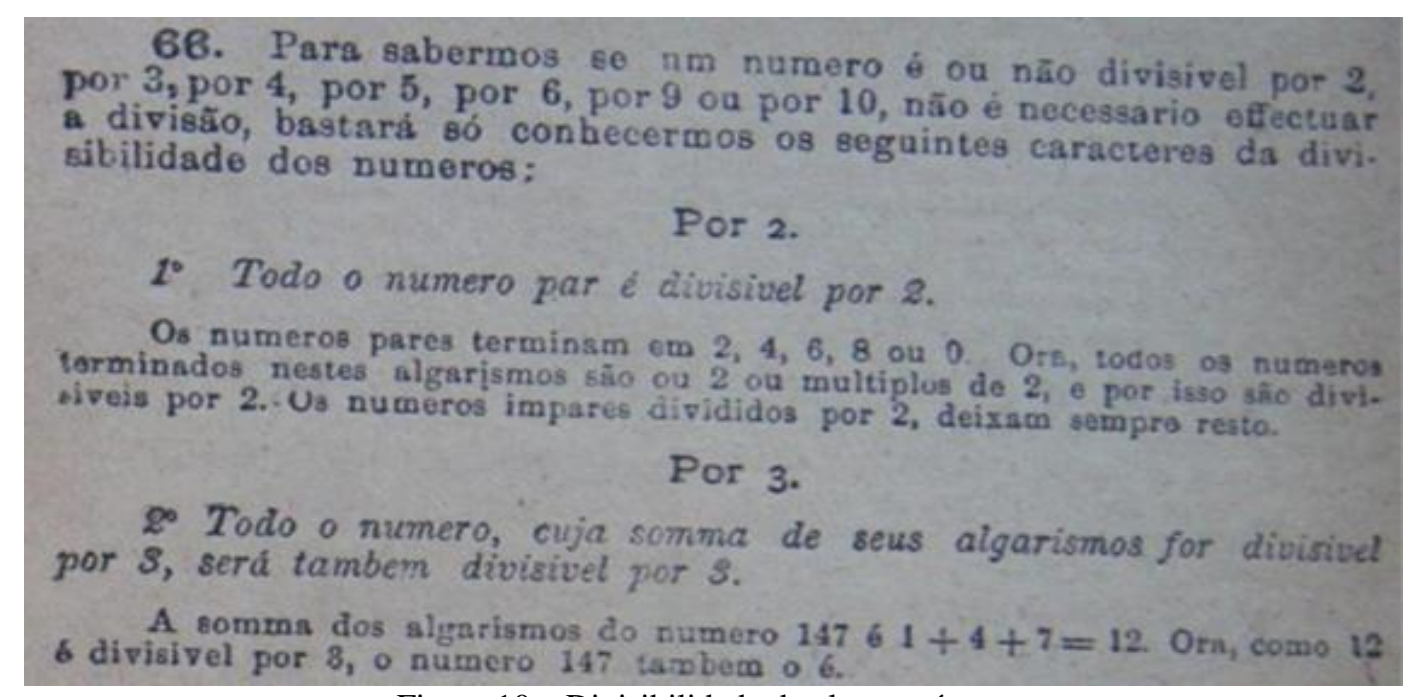

Figura 10 - Divisibilidade de alguns números

Fonte: Trajano (n.d., p. 37)

Esta breve análise realizada nos permitiu verificar que a Arithmetica Primaria, de Antônio Trajano, foi dividida em tópicos, acompanhados de definição, bem como de alguns problemas solucionados, seguidos da elaboração de numerosos exercícios a serem trabalhados. 
DOI: https://doi.org/ 10.20396/zet.v27i0.8654072

Como exposto, após o autor ter abordado as regras e as definições de cada conteúdo estudado, procurava expor como utilizá-las para solucionar problemas. Propôs outros enunciados, começando com o mesmo grau de dificuldade, o qual ia aumentando gradativamente, para que o aluno conseguisse solucionar os exercícios e os problemas variados.

Com relação ao procedimento metodológico utilizado por Antônio Bandeira Trajano para compor a Arithmetica Primaria, baseado na análise desenvolvida ao longo da pesquisa, só nos resta considerar, com algum respaldo, que esse autor se apoiou no método intuitivo. $\mathrm{O}$ uso e a exploração apropriados de figuras estavam diretamente ligados aos estímulos visuais propostos. Vejamos um dos postulados desse método.

E aquele que em todo ensino faz apelo a esta força sui generis, a este olhar do espírito, a este ímpeto espontâneo da inteligência em direção da verdade. Ele consiste não na aplicação de um ou outro procedimento, mas na intenção e no hábito geral de fazer agir, de deixar agir o espírito da criança em conformidade com o que nós chamávamos a pouco de instintos intelectuais. (Buisson, 1897, p. 9)

Por meio desse artifício metodológico, o autor auxiliava o aluno a observar e praticar as regras aritméticas, as quais a questão estava vinculada, de modo que o raciocínio lógicomatemático viesse a ser construído de maneira perceptiva e reflexiva.

\section{Considerações finais}

Esta pesquisa teve a intenção de desenvolver uma análise, de caráter histórico, da obra Arithmetica Primaria, de Antônio Bandeira Trajano, destinada a meninos e meninas que começavam o estudo da Aritmética nas escolas primárias, para tanto nos valemos da sua 12. ${ }^{\text {a }}$ edição. Com o intuito de desvelar o emprego do método intuitivo na sua elaboração, buscamos nos aprofundar no estudo dessa metodologia de ensino que parte do simples para o complexo, do conhecido para o desconhecido, do concreto para o abstrato, ou seja, uma "concepção filosófica e científica pela qual a aquisição de conhecimento advinha dos sentidos e da observação", conforme Souza (2000, p. 16).

Essa metodologia, segundo alguns registros analisados e dispostos no corpo deste artigo, mesmo em tempo anterior à chamada Reforma Leôncio de Carvalho (Decreto n. ${ }^{\circ}$ 7.247, de 19 de abril de 1879) e à experiência vivenciada pela Escola Americana, de São Paulo, já estava presente em diversos estados do Brasil,

Ao analisar o nosso objeto de estudo, Arithmetica Primaria, de Antônio Bandeira Trajano, constatamos aí indícios da utilização do método intuitivo, quando, por exemplo, logo abaixo de algumas ilustrações, havia o seguinte anúncio: "Ensino intuitivo da figura", ou seja, era um modo de ensinar Aritmética no qual, se a figura fosse retirada, seria mais difícil responder às perguntas, pois o recurso da visão auxiliaria a intuição, ou seja, as ilustrações eram utilizadas como uma metodologia de ensino, contemplando as orientações do método 
DOI: https://doi.org/ 10.20396/zet.v27i0.8654072

intuitivo. $\mathrm{O}$ autor também propunha uma inversão na forma tradicional de apresentar os conteúdos. Ao invés de apresentar os conceitos, as definições, as regras e os procedimentos, seguidos de exemplos e com propostas de exercícios e questões para serem resolvidos pelos alunos ao final, ele apresentava uma questão e sua solução antes da regra, ou colocava problemas no "estudo intuitivo da figura" no início das lições das operações fundamentais.

Em suma, intentamos mostrar que a cultura escolar vai, aos poucos, se adequando aos novos tempos e se transformando em novas concepções de ensino. Do método intuitivo, que circulou do final dos oitocentos ao início do século XX ao momento atual, muito se alterou na prática docente em Matemática (e particularmente em Aritmética). Muitas foram, são e continuarão a ser as procuras e os caminhos que a instituição escola trilhou e trilhará: são conteúdos que são retirados ou inseridos nos programas, metodologias que são buriladas a fim de oferecer melhores resultados.

\section{Referências}

Aranha, M. L. A. (1996). História da Educação (2a ed.). São Paulo: Moderna.

Auras, G. M. T. (2005). Uma vez normalista, sempre normalista: a presença do método de ensino intuitivo ou lições de coisas na construção de um habitus pedagógico (escola normal catarinense 1911-1935). Tese de Doutorado em Educação, Universidade Federal do Paraná. Retirado em 18 de junho, 2013, de: https://acervodigital.ufpr.br/bitstream/handle/1884/2984/Tese\%20Gladys\%20Mary\%20T eive $\% 20$ Auras.pdf? sequence $=1 \&$ isAllowed $=y$.

Barbosa, R. (1950). Lições de Coisas. In R. Barbosa, Obras completas (vol.XIII t). Rio de Janeiro: Ministério da Educação e Saúde.

Bittencourt, C. M. F. (1993). Livro didático e conhecimento histórico: uma história do saber escolar. Tese de Doutorado em História Social, Faculdade de Filosofia, Letras e Ciências Humanas da Universidade de São Paulo.

Buisson, F. (1897). Conférence sur l'enseignement intuitif. In Conférences pédagogiques faites aux instituteurs delegues à l'Exposition Universelle de 1878. Paris: Librairie Ch. Delagrave.

Cambi, F. (1999). História da pedagogia. São Paulo: Fundação Editora da UNESP (FEU).

Carneiro, R. S. (2014). O método intuitivo na aritmética de Calkins e Trajano. Dissertação de Mestrado em Educação Matemática, Universidade Severino Sombra, Vassouras-RJ.

Certeau, M. (2007). A escrita da história (2a ed.). Rio de Janeiro, RJ: Forense Universitária (Obra original publicada em 1975).

Chartier, R. (1990). A história cultural: entre práticas e representações (M. M. Galhardo, Trad.). Rio de Janeiro: Bertrand Brasil S. A. (Obra original publicada em 1988).

Chervel, A. (1990). História das disciplinas escolares: reflexões sobre um campo de pesquisa. Teoria \& Educação, 2, 177-229. Porto Alegre: Pannonica.

Choppin, A. (2004, set./dez.). História dos livros e das edições didáticas: sobre o estado da arte (M. A. C. Cappello, Trad.). Anais do XXII Congresso do ISHEE (2000, Alcalá, 
DOI: https://doi.org/ 10.20396/zet.v27i0.8654072

Espanha), Revista Pedagogia Histórica, 38(1), 21-49, 2002; Educação e pesquisa, 30(3), FEUSP, São Paulo.

Decreto $n .^{\circ} 7.247$, de 19 de abril de 1879. (1879). Reforma do ensino primário e secundário no Município da Corte e o superior em todo o Império. Retirado em 12 de maio, 2013, de: http://www2camara.gov.br/legislacao/publicacoes/doimperio.

Julia, D. (2001). A cultura escolar como objeto histórico (G. de Souza, Trad.). Revista Brasileira de História da Educação, 1, 9-43. São Paulo, Campinas: Autores Associados.

Leite, T. R. (1870). Instituto dos Surdos-Mudos: relatório do diretor. Relatório apresentado a Assemblea Geral na Segunda Sessão da Decima Quarta Legislatura pelo Ministro e Secretario dos Negocios do Imperio, Paulino José Soares de Souza. Retirado em 16 de junho, 2014 , de: http://memoria.bn.br/DocReader/DocReader.aspx $? \mathrm{bib}=720968 \& p e s q=$ methodo\%20intuit ivo\&pasta $=$ ano $\% 20186$.

Matos, A. S. (2004). Os pioneiros presbiterianos do Brasil (1859 - 1900): missionários, pastores e leigos do século 19. São Paulo: Cultura Cristã.

Pinheiro, N. V. L. (2013). Escolas de práticas pedagógicas inovadoras: intuição, escolanovismo e matemática moderna nos primeiros anos escolares. Dissertação de Mestrado em Educação e Saúde na Infância e na Adolescência, Universidade Federal de São Paulo, Escola de Filosofia, Letras e Ciências Humanas, Guarulhos.

Souza, R. F. (2000). Inovação educacional no século XIX: a construção do currículo da escola primária no Brasil. Cadernos Cedes, ano XX, 51, 9-28.

Trajano, A. B. (n.d.). Arithmetica Primaria (12a ed.). Rio de Janeiro: Livraria Francisco Alves.

Valdemarim, V. T. (2004). Estudando Lições de Coisas. Campinas: Autores Associados.

Valente, W. R. (2007). Interrogações metodológicas. Revista Eletrônica de Educação Matemática-REVEMAT, 2(2), 28-49.

Valente, W. R. (2011). A educação matemática e os estudos históricos comparativos: de sua legitimidade à sua viabilidade. Anais do XIII CIAEM-IACME, Recife, Brasil, 2011. Retirado em 20 de janeiro, 2014. de: <http://lematec.net/CDS/XIIICIAEM/artigos/MP1valente.pdf $>$.

Vidal, D. G. (2000). Escola nova e processo educativo. In: E. M. T. Lopes, L. M. Faria Filho \& C. G. Veiga, 500 Anos de Educação no Brasil (pp. p. 371-398). Belo Horizonte: Autêntica.

Villela, L. M. A. (2009). "GRUEMA”: uma contribuição para a história da Educação Matemática no Brasil. Tese de Doutorado em Educação Matemática, Universidade Bandeirante de São Paulo, São Paulo.

Villela, L. M. A. (2010). "GRUEMA”: uma contribuição para a história do livro didático e da matemática moderna no Brasil. In X Encontro Nacional de Educação Matemática. Salvador/BA. Retirado em 19 de novembro, 2013. de: http://www.lematec.net/CDS/ENEM10/artigos/CC/T6_CC1875.pdf.

Viñao, A. (2008). História das disciplinas escolares (M. F. Braga, Trad.). Revista Brasileira de História da Educação, 18, 173-215. Retirado em 07 de novembro, 2012, de: http://www.rbhe.sbhe.org.br/index.php/rbhe/article/view/93. 